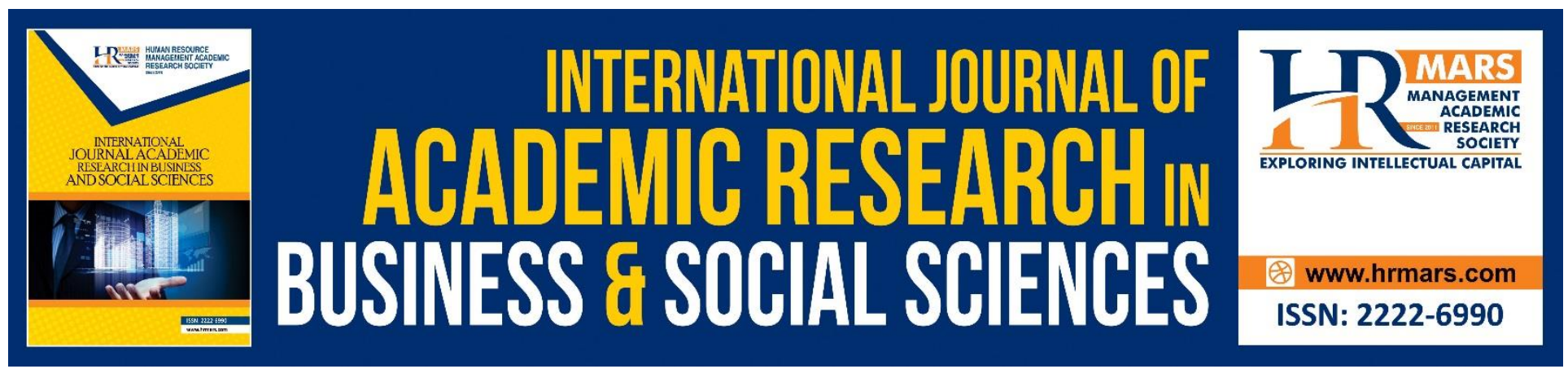

\title{
Negotiating Hyphenated Identities in the Selected Poems of Hilary Tham
}

Khoo Siow See, Ruzy Suliza Hashim, Raihanah M.M.

To Link this Article: http://dx.doi.org/10.6007/IJARBSS/v8-i8/4622 $\quad$ DOI: $10.6007 /$ IJARBSS/v8-i8/4622

Received: 19 June 2018, Revised: 28 July 2018, Accepted: 30 July 2018

Published Online: 21 August 2018

In-Text Citation: (See, Hashim, \& Raihanah, 2018)

To Cite this Article: See, K. S., Hashim, R. S., \& Raihanah, M. M. (2018). Negotiating Hyphenated Identities in the Selected Poems of Hilary Tham. International Journal of Academic Research in Business and Social Sciences, $8(8), 659-673$.

\section{Copyright: (C) 2018 The Author(s)}

Published by Human Resource Management Academic Research Society (www.hrmars.com)

This article is published under the Creative Commons Attribution (CC BY 4.0) license. Anyone may reproduce, distribute, translate and create derivative works of this article (for both commercial and non-commercial purposes), subject to full attribution to the original publication and authors. The full terms of this license may be seen at: $\underline{\text { http://creativecommons.org/licences/by/4.0/legalcode }}$

Vol. 8, No. 8, August 2018, Pg. 659 - 673

http://hrmars.com/index.php/pages/detail/IJARBSS

JOURNAL HOMEPAGE

Full Terms \& Conditions of access and use can be found at http://hrmars.com/index.php/pages/detail/publication-ethics 


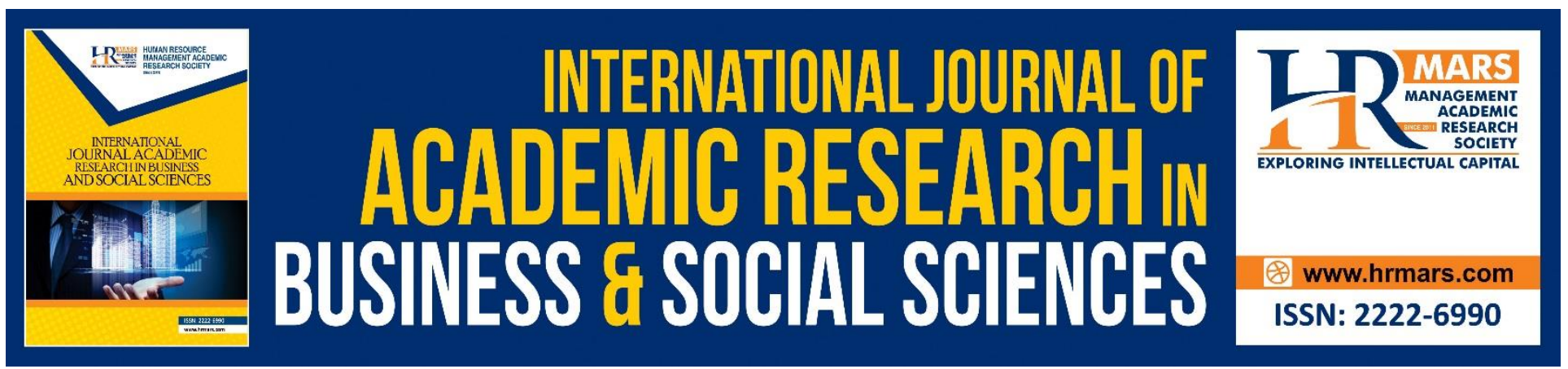

\title{
Negotiating Hyphenated Identities in the Selected Poems of Hilary Tham
}

\author{
Khoo Siow See, Ruzy Suliza Hashim, Raihanah M.M. \\ School of Language Studies and Literature, Faculty of Social Sciences and Humanities, Universiti \\ Kebangsaan Malaysia, Malaysia
}

\begin{abstract}
Hilary Tham, primarily known as a Chinese-Malaysian-American poet, makes use of her rich AsianChinese heritage in the various anthologies she has written throughout her life in America. She plays the role of cultural mediator by translating cultural artefacts she grew up with and aspects of the American culture she has embraced. In this paper, we explore the way Tham negotiates her multiple cultural identities through her selected poems by employing cultural translation as a lens. In the analysis, the translation of multiple cultures is centered thematically on food culture, parenting culture, old age culture, ancestor worship culture, funeral culture, and expression of love culture. We argue that the hyphenated identities negotiated in Tham's selected poems are heterogeneous, multifaceted, polyphonic, and never unilateral by characterization. Although Tham is conscious of her role and agency as a cultural mediator in communicating the cultural differences of Asian-Chinese immigrants to her American audience, she negotiates the imbalanced power relations in most of the cultural issues and problematizes the "in-betweenness" of cultural identities, which culminates in the creation of a "Third Space" that fuses the East and the West as part of her cultural being. By way of implication, the focus on hyphenated identities through the lens of cultural translation contributes to the creation of cultural consciousness and mutual understanding of cultural variations between East-West cultures in Asian and American communities.
\end{abstract}

Keywords: American-Jewish Cultures, Cultural Translation, Hyphenated Identities, Asian-Chinese Heritage, Third Space.

\section{Introduction}

In this paper, we focus on Hilary Tham's poetry featuring the cultural aspect of her works, namely negotiating her hyphenated selves that engage with her doubly dispersed Asian-American cultural identities evoked in her poems. Tham is primarily known as a prolific Chinese-Malaysian-American poet, who makes use of her rich Asian-Chinese heritage and American-Jewish cultures in her writing of various anthologies throughout her life in America. She first grew up in the world of Chinese Taoism and Confucianism. She embraced Judaism after marriage, having married an American-Jewish husband. Hence, her works display Chinese myths and beliefs, and Judaism to a certain extent. The echoes of Chinese-Malaysian upbringing in her works were greatly influenced by her mother, who 
INTERNATIONAL JOURNAL OF ACADEMIC RESEARCH IN BUSINESS AND SOCIAL SCIENCES

Vol. 8, No. 8, August 2018, E-ISSN: 2222-6990 @ 2018 HRMARS

instilled in her the myths of Gods. The heterogeneous cultures between the East and the West reflected in her poetry emerge as a consequence of her interracial relationship, where living in America offers different perspective of existence and identity. Hall (2003:234) asserts that cultural identity is not something which already exists, but is rather formed from the past; it also undergoes constant transformation and it is a matter of "becoming" as well as of "being". Tham carries her fractured selves from her Malaysian homeland to American, her adopted homeland, further complicating her relocation of identity from being Chinese-Malaysian to becoming Asian-AmericanJewish. These fraught negotiations of Tham's dissolved cultural identities are never unilateral. Cultural translation is required when mediating cultural identities and crossing cultural borders. Thus, the current paper aims to explore the way Tham negotiates her multiple cultural identities through her selected poems by employing cultural translation as a lens. In short, we intend to show the way cultural identities are represented and mediated in Tham's poetry.

\section{Literature Review}

Hilary Choy-Kam Tham was born in 1946 in Klang, Selangor, Malaysia. She received her primary and secondary education from Klang Convent School. She pursued her tertiary education at University Malaya, where she majored in English Literature and graduated with a Bachelor of Arts, Upper Class Honors, from 1967 to 1990. Tham authored eight anthologies of poetry, a memoir, and an anthology of short stories. Her first volume of poetry, No Gods Today, was published in 1969 in Malaysia. Consequently, her second volume of poetry, Paper Boats was published in 1987. Her anthologies of poetry that followed were all published in the United States, namely: Bad Names for Women (1989), Tigerbone Wine: Poems (1992), Men and Other Strange Myths: Poems and Art (1994), Counting (2000), Reality Check and Other Travel Poems and Art (2001), and The Tao of Mrs. Wei (2003). Tham's memoir, Lane with No Name and Poems of a Malaysian-Chinese Girldhood, was published in 1997 and her short stories anthology entitled Tin Mines and Concubines was published in 2005. Her poems are rooted in two rich traditions that are woven into a complex tapestry, engaging the great themes of life-from love, death, grief to joy providing a work of exacting art. Meanwhile, her poetry is also the reflection of her soul and mind that provides her the space to share her thoughts and experiences, to celebrate the world she lives in, and to cherish the cultures that nourished her growth.

In Tham's oeuvre, she mainly accesses a wide range of themes ranging from human relationships to personal feelings, gender, culture, religion, and ecological concerns. Gender issue is one of the central themes of her works in which she echoes a strong feminist voice in the rich Chinese cultural framework that she was brought up. Similarly, Fadillah Merican, Ruzy Suliza Hashim, Ganakumaran Subramaniam and Raihanah M.M (2004:105) remark that Tham's works are more Chinese-oriented and preoccupied with women issues. Nor Faridah Abdul Manaf and Ruzy Suliza Hashim (2002:197) highlight the notion of the mother-daughter relationship in the examination of her memoir, Lane with No Name (1997). They argue that the character of a mother shapes the personality of the daughter. For instance, the portrayal of the strong character of Tham's female identity in her memoir is actually affected by her mother, who struggles to survive in a typical Chinese patriarchal society. They also contend that the male- dominant Asian society has forced women to become tough, and to possess a strong survival spirit to weather any harsh circumstances leading to the strengthening of the bond between mother and daughter. For example, Tham spiritually supports her mother, who is faced with the constant betrayal of her father's infidelity, as she could feel the suffering and loneliness that her mother felt. Tham's mother could be perceived as weak, submissive, traditional, reserved, and selfsacrificing through the lens of Western feminists but via the Eastern feminist model, Tham's mother 
INTERNATIONAL JOURNAL OF ACADEMIC RESEARCH IN BUSINESS AND SOCIAL SCIENCES

Vol. 8, No. 8, August 2018, E-ISSN: 2222-6990 @ 2018 HRMARS

actually possesses the qualities of Asian women, the image of a good woman, who is resilient while also performing the roles of a mother and wife. Asian women, who live under male subjugation are trained to be tough to survive any severe conditions, thus bringing positive impact, a characteristic that resonates well with Asian feminists.

Tham's memoir reveals a female perspective that is distinctively Chinese. In Tham's memoir, Lane with No Name (1997), Siti Aishah (2005:38) reveals the psyche of female Chinese diaspora that Tham experiences throughout the three stages of her life, beginning from her childhood and adolescence up to her adult years. She explores the female psyche in Tham's works via feminism, psychoanalysis, and new historicism with the concepts of identity search, powerlessness, alienation, social displacement, and marginalization. She argues that the Chinese women diaspora are very much influenced by the traditional way of their cultural practices. Raihanah M.M (1999) remarks that a woman starts to "renegotiate her own identity, her heritage, and her story based on what she has experienced in her formative years" (Siti Aishah, 2005:2). Based on this premise, Siti Aishah agrees that the Tham's female identity is constructed through her constant development in every stage of life.

Apart from that, the notion of selfhood and the appreciation of personal liberty from examining female portrayal and identity are another aspect that can be extracted from Tham's works. In Tham's poetry, Paper Boat (1969), Nor Faridah Abdul Manaf and Mohammad A. Quayum (2003:105) assert that Tham promotes individualism and freedom for personal happiness, as she believes true happiness for oneself can only be achieved via self-support without control from any external authority. Paper Boat (1969) depicts the objection against the traditional values of oppressing women especially the marital issues in a patriarchal society. On the one hand, most women are victimized into an unhappy marriage in which their selfhood is threatened. In addition, they also succumb to societal pressures. On the other hand, the husbands are granted the freedom to have extramarital affairs. In Paper Boat (1969), Tham discloses the inequality between both genders when it comes to gaining freedom. Based on her own life experiences, issues of female powerlessness dominate her literary discourse.

Tham's poems also engage with the elements of ecology, where the agent of nature that covers the themes of life, gender, and environment are used. When viewing Tham's poetry, Fadillah Merican et al. (2004:108) contend that many of her poems show the elements of nature in connection with her Malaysian upbringing. For instance, the metaphor of lalang in Sitting in Grass (Tham, 1969:41) indicates the parallelism of plant wilderness with the growth of a young woman. Lalang is a Malay noun, which means a kind of grass with sharp blades that can easily cut undiscerning trespassers. This poem reads as an illustration of a young woman's journey of self-discovery. In another poem, Vocation (Tham, 1969:14), the use of crows as a metaphor portrays humans who live in the dichotomy of two worlds. Her work attempts to reflect the versatility of crows and human beings in adapting to a new environment, as from a scientific point of view, crows are the smartest and most adaptable birds. Tham clearly presents the domestication of her poetic landscape via the application of lalang leaf and the crows as a metaphor.

It seems that most of Tham's critical works uncover her Chinese, and female identity issues as well as ecological concerns. She highlights predicaments of her persona primarily through culture. As mentioned earlier, her upbringing problematizes her cultural identities. Tham articulates her Chinese-oriented upbringing together with her conflicts of living in both Asian and American cultures in her literary works. In fact, her multiple identities bridge the gap between Chinese-Malaysian and American-Jewish cultures; she reflects most of the Asian-American cultural issues that she 
INTERNATIONAL JOURNAL OF ACADEMIC RESEARCH IN BUSINESS AND SOCIAL SCIENCES

Vol. 8, No. 8, August 2018, E-ISSN: 2222-6990 @ 2018 HRMARS

experiences in many of her poems. However, the exploration of her hyphenated identities through the cultural translation framework in her critical works seems lacking. Thus, this study focuses precisely on the features of translating Tham's diverse cultural world from selected anthologies of poetry that she wrote and suggests that it is her hyphenated identities that bring about the matter of cultural differences and the imbalanced negotiations of power between cultures.

\section{Cultural Translation as a Lens}

Cultural translation is a matter of embracing cultural interpretation and cultural communication. It can be termed as the interaction between different cultural groups as well as the connection of culture and translation. Traditionally, translation engages with the transaction between dual languages that comprise the movement between texts and undergoes the examination processes of encoding and decoding. Nevertheless, translation studies of today operate not only between languages but also between cultures. To quote the Italian novelist and literary critic, Umber Eco, "Translation is always a shift not between two languages but between two cultures" (Lambert, 2008:1). Contemporary translation studies include the movement of people that deal with the negotiation between two or more cultures. According to Wang (2008:75), translation has expanded its function widely from a linguistics discipline to cultural interpretation in the current era of globalization, where cross-cultural practices are required to connect the world and the people from various cultural backgrounds or nations who speak different languages. Translation plays an essential role in bridging diverse nations and creates the platform for crossing cultural and linguistic boundaries. In other words, translation embraces inter-lingual and inter-cultural communication. Inter-cultural practices always enmesh in a set of power relations that emerge from diverse cultures. Bassnett (1998:135) states that cultural translation includes both the inter-disciplines of translation studies and cultural studies that are primarily concerned with the matters of "power relations and textual production". Meanwhile, Asad contends that, "cultural translation is an institutionalized practice that results from the differentials of power that separate societies" (Maitland, 2017:11). Indeed, cultural translation encounters the same negotiation of power with the postcolonial theory that Munday (2016:210) asserts, in which power negotiation is the dominant intersection of translation studies and postcolonial theory. Certainly, for translation studies, from a postcolonial perspective, Bery (2007:7) remarks that it has to connect with power differentials among nations, languages and cultures. Both cultural translation and postcolonial theory struggle with an unequal power relationship among cultures such as the negotiation between existing and adopted culture. Nevertheless, cultural translation accentuates the negotiation of power relations and cultural differences.

The idea of cultural translation originated from Homi Bhabha (1994), the postcolonial and Indian cultural theorist (Bery, 2007:7). Bhabha's notion of cultural translation can be appropriated in translation studies because it directly connects with the concepts of hybridity, the "in-between" and the "third space". In cultural translation, the notion of hybridity is the assimilation of cultures or the cross-cultural exchange, which is found in the third space to foster the interaction between cultures, whereas the "in-between" space carries the ambivalent space that forms the "third space" and the notion of "The Other". The concept of "third space" is actually constructed between central and marginal cultures. This is a place where variation interacts and consequently shapes a new cultural production and new cultural identity without reflection or mimicry. Besides that, the contradictory and ambivalent space emerging in the "third space" also leads to the exoticism of cultural diversity in addition to the cultural identity that empower hybridity and the operation of cultural differences. 
INTERNATIONAL JOURNAL OF ACADEMIC RESEARCH IN BUSINESS AND SOCIAL SCIENCES Vol. 8, No. 8, August 2018, E-ISSN: 2222-6990 @ 2018 HRMARS

Maitland (2017:13) argues that the migrant engages with the "war of position" by encountering the "in-between" space either to stay at the migration process or assimilates into a new culture, which cause the flux of cultural identity and cultural difference with constant negotiation. Maitland states that this is, "the space of negotiation that Bhabha calls cultural translation, for it is transgressive, blasphemous, and contestatory." It is the "in-between" space that conveys the meaning of culture differentiation and creates the negotiation of imbalance and inequality of power relations, which underlies cultural translation.

However, when it comes to negotiating cultural identity, the cultural mediator plays an important role in interacting and translating cultures. Cultural translation, as Katan (2004:16) asserts, requires a mediator, a specialist in negotiating and understanding between cultures or a so-called "crosscultural specialist", to translate the culture of origin towards the receiving culture and vice versa. There will be no interaction among cultures without the cultural mediator. Furthermore, it is crucial to have a cultural mediator, who has other cultural exposures besides the acquaintance of her own culture in cultural translation. Similarly, Lian (2013:209) comments that true cross-cultural understanding can only be achieved through the process of translation as the individual experiences self-discovery by encountering the differences of a foreign culture. Tham's cultural upbringing is ideally fitted for the position of cultural mediator. Tham as a cultural mediator is placed at the middle ground of hybridity or the so-called intercultural place to occupy a space "in-between", which is located in the Third Space. Munday (2016:212) proclaims that Bhabha applied the interconnected concepts of "in-betweenness", "third space", "hybridity" and "cultural difference" to theorize the matters of identity, agency and belonging in the process of "cultural translation". All of these interrelated concepts, covered in the theoretical perspective of cultural translation are applied for interpreting the inter-cultural texts written by Tham. The present article sets out to explore the insights of different cultural practices that Tham negotiates in the Third Space of her cultural identities in her selected poems through Bhabha's notion of cultural translation.

\section{The Analysis}

For the analysis of Tham's selected works, we chose poems from seven of her anthologies, namely: Paper Boats (1987), Bad Names for Women (1989), Tigerbone Wine: Poems (1992), Men and Other Strange Myths: Poems and Art (1994), Counting (2000), Reality Check and Other Travel Poems and Art (2001), and The Tao of Mrs. Wei (2003). Only poems that are relevant to cultural matters are selected for the analysis. All of her selected poems reflect different aspects of her experiences with Asian and American cultures. Tham provides insights into her dual consciousness of these multiple cultures such that the idea of cultural translation presents the theoretical framework for understanding the dichotomies between the cultures in the East and West. The translation of multiple cultures in this analysis is centered thematically on food culture, parenting culture, old age culture, ancestor worship culture, funeral culture, and expression of love culture. The following subsections present the thematic analysis:

\section{The Food Culture}

The notion of food is an essential part of culture that most of the ethnicities embrace their cultural heritage via the culture's food. Tham applies the image of food as a manifestation of the East-West culture throughout her various poems. She integrates the images of animals and foods in the articulation of assorted cultures - from Asian-Chinese culture to the American culture-all of which have distinctive cultural practices. 
Tham demonstrates cultural differences through the interplay between images of animals and foods. She illustrates how cultures signify the function of specific animals, such as snakes, rabbits and dogsfrom being eaten as delicacies in Chinese culture to being house pets in the American ethos. In the poem, A Matter of Perspective (Tham, 1994:50), the Western father keeps the snake as a house pet in a special box but the Chinese father stews the snake with Chinese herbs to make a meal. Akin to another poem of Tham's, Animals or Extrapolations of Love (Tham,1994:80), while American daughters keep their rabbits in a cozy bed at home, rabbits are massively produced in China for commercial and food purposes. As illustrated in the poem, Americans limit each household to keeping "three rabbits and three hutches" compared with "ten rabbits and fifty hutches" for each household in Sichuan, China. Meanwhile, in Mrs. Wei Goes to the Dogs (Tham, 2003:46), where some dogs such as Mongrels are man's best friend and house guards that bring luck to the home, Mrs. Wei claims that dogs' blood is good to eat as nutritious food "like vitamin E or rhino horn." The same scenario happens in Roach Territory (Tham, 1992:44), whereas the American husband treats the cockroach as a horrific and disgusting insect, it turns out to be a sort of food and medicine for the Chinese mother-in-law, who catches the cockroach with bare hands and makes roach gut tea because she believes it is good for the treatment of asthma.

Tham attempts to show that the notion of food is important in Chinese culture and that the Chinese are inseparable from their food culture. The specific animals served in Chinese cuisines are included in Chinese culture but excluded by the Western culture. The cultural differences that Tham delineates between the East and the West are embedded with challenges and cultural sensitivity. The metaphors of foods and animals create tensions between dual cultures. Westerners view the consumptions of specific animals, pets, and animal organs in Chinese culture as "The Other" and strange. The Chinese personas depicted in the poems experience a sense of "in-betweenness" and ambiguities in their cultural identity when placed in the Western cultural domain. Although they have assimilated into the Western culture, their Asian-Chinese-born cultural practices contradict with their adopted cultures. In fact, the potential pets that Tham includes on the Chinese menu are closely connected with the starvation history in China that has been passed on throughout ancient generations bringing about this ingrained and deep-rooted culture. According to Xu (2008:1), millions of people in China suffered from hunger and only the minority elite could afford to obtain food using their wealth during the Chinese Cultural Revolution from 1966 until 1976. Consequently, the consumption of pets and all sorts of animal organs are not unusual in Chinese culture. Also, the Chinese practice the virtue of frugality and the value of food appreciation. However, the consumption of specific animals and pets are not that foreign in the Western culture. For instance, Ratnasiri and Bandara (2017) mention that kangaroo meat was seen as pet food in the past, but currently the Australian per capita consumption of kangaroo meat has increased tremendously compared to the consumption of beef and lamb, which has declined over the past two decades.

\section{The Parenting Culture}

Tham builds on the East-West dialogue that evokes cultural variations in parenting through her poem, Mrs. Wei Feeds Her Children (Tham, 2003:61). The poem sets a conversational form between a Chinese-Malaysian mother, namely Mrs. Wei and some American mothers. She displays the way two cultures carry out family education through food appreciation.

Tham seeks to reveal the contrastive parenting practices between Chinese-Malaysian and American cultures. Even though Mrs.Wei is portrayed as Chinese-Malaysian mother, Tham incorporates Malaysian-Chinese parenting with the Chinese parenting under the roof of Asian Chinese parenting 
INTERNATIONAL JOURNAL OF ACADEMIC RESEARCH IN BUSINESS AND SOCIAL SCIENCES Vol. 8, No. 8, August 2018, E-ISSN: 2222-6990 @ 2018 HRMARS

in the poem. She perceives American parenting as gentle and loving, whereas Chinese parenting is seen as authoritative and commanding. In the poem, American mothers educate their children to appreciate food by telling them the story of starvation in Poland, hoping their children would learn through the story. However, Mrs. Wei opposes the American mothers by saying, "That wouldn't have worked for us-in Malaysia, people were starving in our town" (Tham, 2003:61). Due to the different upbringing and cultural backgrounds of Malaysian children, the American mothers' style of parenting is not applicable to the Malaysian parenting cultural context because there are Malaysians who still suffer from famine and poverty such as that suffered by the Polish. In contrast to American parenting, Mrs. Wei educates her children about food appreciation in a strict and threatening manner by telling them an "old wives" tale or the traditional folk beliefs in which their children will get an ugly spouse in the future if they left the table with rice in the bowl, as illustrated in the poem, "Come back! You left ten grains of rice in your bowl. You'll offend the God of Planting. Do you want to put pockmarks on the face of your future wife?" (Tham, 2003:61) Similarly, Mrs. Wei educates her children on Chinese dining etiquette in the same manner, "Eat your rice, watch your chopstick hand, keep your palm up. Never turn the back of your hand to Heaven, the gods will mark you for rebellious thoughts" (Tham, 2003:61). Her intention is to teach her children to be polite and respect Chinese table manners, yet her tone of voice does not sound friendly to the children. She holds the restrictiveness and harshness of Asian parental control over her children. Ostensibly, Tham creates the dichotomies of soft-spoken American mothers versus fierce Chinese mother by image.

Apart from mediating cultural differences, Tham seems to negotiate the imbalance in power relations between Chinese and American parenting. Bery (2007:13) asserts that cultural translation is more engaged with difference and otherness, especially those cases where there are considerable power differentials. The representation of Mrs. Wei is undoubtedly engaged with the objectification of American others as much as she herself is objectified. Despite integrating the American community, Mrs. Wei performs her Chinese way of parenting inherited from her mother from past generations, as she articulates in the poem, "I told my children the same things my mother told me..." (Tham, 2003:61). From this, there emerges a sense of otherness to the American culture. Tham shows more respect towards American parenting rather than negates it but she appears to disapprove of Chinese parenting although her actual attempt was to reveal another facet of Chinese parenting. This mirrors the imbalanced negotiations of power between cultures. Tham sets the binaries of affectionate American parenting versus hostile Chinese parenting, which seems unauthentic to Chinese culture. Chua (2011:51) states that Western mothers show more concern about their children's self-esteem or psyches whereas the Chinese mothers advocate "tiger parenting" but she does not standardize all mothers of Chinese ethnicity as "Chinese mothers" and "tiger moms", just as Western parenting does not apply to all Western mothers. In addition, the "old wives" tale retold by the Chinese mother sounds impractical for the younger generation since most young Chinese mothers today are not really familiar with "old wives" tale when compared with mothers in the olden days. Furthermore, not all Asian children are obedient like Mrs. Wei's children, whether or not they have authoritative parents. Most children nowadays are brought up to speak their thoughts, and can exercise their own voice, besides being able to have mutual communication with their parents. Thus, the parenting styles depicted by Tham in her poem cannot be generalized culturally since different parents implement different ways of parenting despite the culture they originated from. 
INTERNATIONAL JOURNAL OF ACADEMIC RESEARCH IN BUSINESS AND SOCIAL SCIENCES

Vol. 8, No. 8, August 2018, E-ISSN: 2222-6990 @ 2018 HRMARS

\section{The Old Age Living Culture}

Tham's Mrs. Wei Moves Her God to America (Tham, 2003:70) depicts much of the elderly living style in the East-West cultures. The poem shows the contradiction between the Asian-American woman who mixes Chinese and American old age living cultures in America that generates culturally conflicting matters.

In the poem, Tham juxtaposes the Oriental and American elderly lifestyles through the portrayal of Mrs. Wei, a devoted and superstitious Chinese Taoist woman, who carries along her Chinese godsBuddha and Kuan Yin, Goddess of Mercy when moving into her daughter's house in the United States. Mrs. Wei assimilates both the Chinese and American elderly lifestyle in her old age living but she shows more enjoyment of the American lifestyle, as can be traced in the poem:

I hope Buddha and Kuan-yin will like America.

I like America-old people are more alive here,

They don't sit themselves on a dusty shelf

to eat, sleep and wait for death; they take classes

in poetry or movie-making. I love my painting

class. Maybe the gods could use a hobby too. (Tham, 2003:70)

In this poem, Tham describes how Mrs. Wei indulges herself in the American elderly way of living in which she particularly enjoys her painting class. On the one hand, she feels delighted in her leisure activities. On the other hand, she cares about her Gods' feeling and hopes that they will approve of her enjoyment too. She reveals her close-knit bond with her Gods and the equal importance of leisure activities and Gods in her life. However, she harbours mixed feelings due to the clash of her superstitious beliefs with the modern American elderly living lifestyle, which forces her to feel contradiction and anxiety. Although she admires the American elderly way of living, she does not assimilate herself fully into the American culture because she holds tight to her religious roots that have been implanted in her mind subconsciously. It seems that she expects to simultaneously gain spiritual wealth both from her religion and arts appreciation gained from the American culture. Indeed, arts appreciation is one of the ways to enrich one's spiritual mind.

Nevertheless, Tham illustrates clearly the unequal power relations between both cultures. She seems to vilify the Oriental culture but celebrates and elevates the American culture. She portrays how Americans celebrate old age joyfully and feel honoured that they have reached such an age, where they enjoy spending their leisure time with their favourite activities rather than relaxing in the comfort of their home and waiting for the termination of their life, which is ironic to Chinese elderly living. Oriental elderly lifestyle is looked at as inferior, weak, hopeless, and passive whereas American old age is perceived as superior, hopeful, and active. Tham constructs the opposition of pessimistic Chinese old age and the joyful American old age that causes conflicts between the two cultures. The way Tham oppresses and over-generalizes the elderly lifestyles of Asian-Chinese senior citizens is not genuine in Asian-Chinese culture, as not all senior citizens in Oriental communities prefer to spend their days unproductively at home. Furthermore, not every senior citizen lives their old age without any activities and wait for death, unless they fall sick or become physically disabled. Nowadays, most Asian-Chinese senior citizens are not only spending quality time at home with family members but also actively participate in all kinds of social activities with their peers, such as playing mah-jong, practicing Tai-ji also known as internal Chinese martial arts, as well as joining golden age singing competitions and Chinese calligraphy classes. They also celebrate their old age dynamically or live a fulfilling old age lifestyle with all sorts of activities. All in all, the elderly ways of living - whether to 
INTERNATIONAL JOURNAL OF ACADEMIC RESEARCH IN BUSINESS AND SOCIAL SCIENCES

Vol. 8, No. 8, August 2018, E-ISSN: 2222-6990 @ 2018 HRMARS

spend it actively or passively-is determined by the attitude and character of the senior citizen. In other words, culture does not have significant influential power in this matter.

\section{The Ancestor Worship Culture}

Tham mediates the different ways the believers of Chinese-Malaysian-Taoism and Christianity worship their ancestors in Mrs. Wei and Ancestor Worship (Tham, 2003:13). Her poetry reflects the conflicts of cultural practices between two religious groups in the form of an East-West conversation between Mrs. Wei and an Englishman.

The duality of worshipping ancestors between two religious groups creates the dichotomies of cultural insider and outsider that brings about a sense of Otherness to the respective cultural groups. While Mrs. Wei spreads "a feast of roast chicken, moo shu pork, and noodles" (Tham, 2003:13) before her father's grave, an Englishman lays flowers on his mother's grave. When the Englishman asks Mrs. Wei when her father would be coming out to eat the food, Mrs. Wei answers with a smile, "[at the] same time your mother come[s] to smell [the] flowers (Tham, 2003:13)." Both Mrs. Wei and the Englishman aim to worship their ancestors but they encounter tensions in their cultural practices. Ancestor worship is an act of filial piety. It is an annual traditional festival, which is also known as tomb sweeping day or Ching Ming for the Chinese.

The poem sets up a contrast between worshipping the deceased father with food in the Oriental culture and worshipping the deceased mother with flowers in the English culture. Tham interplays the inclusion and exclusion of culture through the images of food and flowers. The way Mrs. Wei offers foods to her ancestors is a ritual practice in Chinese-Malaysian-Taoism. Ironically, the English way of worshipping their ancestors is more in accordance with Christianity. According to Chan (2012:174), only flowers should be presented to honour ancestors as a way of Christians worship ancestors instead of the Chinese sacrificial offerings. However, worshipping ancestors without food offerings is not a Chinese custom. Furthermore, the Englishman also mentions that Christians are not allowed to accept or consume the foods used in Chinese ritual offerings, which conflicts with Chinese ancestor worship. The rejection of the Christians seems to be at the exclusion of Asian-Chinese culture. As mentioned earlier, the notion of food is essential in Asian-Chinese culture but exists in the inclusion of English culture. Thus, when viewing the cultural practices of Mrs. Wei in contrast to the Western way of ancestor worship, her cultural identity is marginalized by the American culture. She is neither Chinese nor American in an American community but she is an Asian-American located in the Third Space. As Bhabha (2006:155) argues, the Third Space is the hybridity in and between cultural variations.

\section{The Funeral Culture}

The customs of respecting the dead vary between cultures and religious groups. Tham provides insights into the American Jewish and Chinese-Malaysian- Taoist ritual practices in mourning the dead in her poetry, At My Father's Funeral (Tham, 2000:77). This poetry reflects a Chinese-Malaysian daughter who is deeply conflicted with the Judaism beliefs that she has converted to while simultaneously being obliged to perform her filial piety by practicing Chinese-Malaysian ritual practices for her deceased father.

In the poem, Tham conveys the thoughts of a Chinese-Malaysian daughter, who is arrested in psychological limbo and has mixed feelings of carrying out her duty to mourn her deceased father in an assimilated Chinese-Malaysian-American-Jewish funeral. When holding the joss-sticks and burning joss-papers during her father's funeral in the Taoist ceremony, she offers Jewish prayers to mourn 
INTERNATIONAL JOURNAL OF ACADEMIC RESEARCH IN BUSINESS AND SOCIAL SCIENCES

Vol. 8, No. 8, August 2018, E-ISSN: 2222-6990 @ 2018 HRMARS

her father by saying "Kaddish, read the Jewish service for the dead" (Tham, 2000:77). Kaddish refers to the "sanctification prayer praising God that is recited by the bereaved daily for eleven months and on the anniversary of death" (Tham, 2000:70). Her ambivalent cultural practices can be traced in the poetry:

Tonight I am holding joss-sticks before a Chinese altar.

It does not matter, though my Rabbi will frown.

It does not matter-I know my father is not here...

I am holding joss-sticks. Blue smoke

perfumes the air. It does not matter

though my Rabbi will shake his head.

He will mention graven images, false idols.

My father was my idol when I was young. (Tham. 2000:77)

Tham draws an iconic parallel between the representation of the persona's father and the rabbi that echoes in the persona's mind during the funeral. She engages the inner dialogue within herself, rethinking her paternal father in her past life and her religious father, the rabbi, who is the Jewish religious leader, as being influential in her current life. There is always a collision between the negotiations when two cultures merge together. The cultural identity of the persona has been problematized, which is reflected in the tug-of-war of her mind. On one side, she has internalized her Chinese-Malaysian tradition by performing the Chinese Taoist death rituals physically. On the other side, she is bound to the rules of Judaism that cannot be violated. Judaism believes in the oneness of God but Taoism worships many different deities. The Chinese funeral involves the viewing of the dead and during the Taoist funeral with-smells of incense and flowers-and the photos of the deceased surrounding the area. In contrast, there is no viewing of the dead in the Jewish funeral, as portrayed in Tham's poem, But a Nice Coffin Wouldn't Hurt, Either (Tham,1994:68) because it is considered impolite to the deceased when holding an "open casket" viewing. According to Chua (2011:104), the burials must take place immediately after death, ideally within twenty-four hours, as per Jewish Law. Nevertheless, the persona's inner conflicting voice goes unheard. She feels uncertain about living inbetween Chinese-Malaysian-Jewish cultural practices in which her hybrid cultural practices place her cultural identity in the Third Space of the American cultural domain and generates the contradictions of a cultural Other versus the notion of Self. Her authentic self is Chinese-Malaysian but her assimilated self is Chinese-Malaysian-American-Jewish, the Chinese Other cum Jewish Other. Wolf (2000:135) argues that:

Cultures are never unitary in themselves, nor simply dualistic as in the relation self/other, rather there is a Third Space, which can neither be reduced to the self nor the other, neither to the First nor to the Third World, neither to the master nor to the slave. Meaning is produced beyond cultural borders and is principally located in the Third Space, a sort of "in-between-space" located between existing referential systems and antagonisms.

These tense negotiations of cultural identities are never one-sided but are placed in the space inbetween the binaries, or the Third Space. Chinese-Malaysian-American-Jewish is the Third Space that Tham constructed in her poem to locate the depiction of the persona and negotiate cultural differences. 
INTERNATIONAL JOURNAL OF ACADEMIC RESEARCH IN BUSINESS AND SOCIAL SCIENCES

Vol. 8, No. 8, August 2018, E-ISSN: 2222-6990 @ 2018 HRMARS

\section{Expression of Love Culture}

Tham illustrates the East-West differences of love expression in her poetry, A Gratitude for Joe (Tham, 2000:93). This poem depicts the intercultural love communication that is evoked from the interracial marriage between a Western husband and an Oriental wife.

When it comes to articulating a cross-cultural relationship, there are always cultural tensions and power relations in the negotiation. Two cultures possess their own way of expressing love, which can be interesting but can also be antagonistic as well, as shown in the poem:

I will bless Joe for making me want

to come West. I will bless this West

where a man kisses his wife on leaving

the house and wants to kiss her again

on his return. Coming from the East,

where love is never spoken, hugging

and kissing are taboo, undignified,

where intimacy flowers and dies in dark

and silences, I want to bless this West

that believes in broadcast-sowing love,

showing tenderness, if only with hackneyed words,

Hallmark cards and advertised roses. (Tham, 2000:93)

The differences of love culture between the West and the East are clearly recognized in the poem. The persona is drawn by physical intimacy that her Western husband displays; in sharp contrast, the Oriental way is not as demonstrative. As described in the poem, Westerners use hugs, kisses, or confessions, send flowers or greeting cards to show their love, whereas Easterners show their love without engaging in physical contact such as kissing and hugging, which is in contrast to the Western culture. The expression of love in Western culture looks romantic, creative, and can be expressed in many ways, either verbally or non-verbally. For instance, the phrase "I love you" is popular in the West. Nonetheless, Tham sees the superficiality and clichéd way of love expression in the West, especially when they express love through "hackneyed words".

Tham polarizes the cultural differences of the East-West love communication by exemplifying the imbalanced power negotiation between two cultures. As Bery (2007:10) remarks, "translation carries the way of attempting to negotiate difference. When one starts to invoke differences of social class as barriers across which translation must occurs, one is beginning to be involved in differentials of power." Tham shows the inharmonious love communication binaries by articulating the Western culture as being more open, aggressive and loving, while the love culture in the East is more conservative, mild and reserved. The differentials of power that Tham negotiates on this particular issue of love expression culture are extremely bias and lacks harmony, as it sets the persona in the inclusion and exclusion of the Oriental and Western culture. The persona is of Oriental blood but she idolizes the Western way of love culture and mortifies with the Eastern way of love expression she originated from. Tham attempts to illustrate the ambiguous hyphenated identity that is located in the in-between status of an Asian-American that has penetrated into a flux identity. The negotiation of the in-between status of the diasporic identity is usually contradicting and problematizes the dichotomy of the self and other.

In fact, Tham indicates that Westerners are more assertive with their emotions and expressions when compared with Easterners, who usually hold back their emotions and expressions. Perhaps, the open- 
mindedness of the West when it comes to love expression is much more influenced by the Western culture, which promotes liberalism, whereas the East is more affected by social structures, family values, and philosophies of Oriental societies. Tham's observation about the issues of love between cultures may be based on the East in the 1960s and 70s. We argue that Eastern marriage of today is not based on such conservatism, as seen in the way the younger generation are being raised by loving and expressive parents. Furthermore, some Easterners would rather express love in a distinctive way by showing practical actions such as care for the psyche of their spouse, preparing food for their loved ones, and sharing the same direction of life to move towards together.

\section{Conclusion}

In conclusion, we argue that the hyphenated identities negotiated in Tham's selected poems are heterogeneous, multifaceted, polyphonic and never unilateral by characterization. The negotiations in-between the interaction of cultural differences reflect the blend of diverse cultures and position the hyphenated cultural identities, Asian-Chinese-American-Jewish, in the Third Space despite the contradictions and ambiguities in the discussions. The layered identities also embrace the inclusion and exclusion of Asian-Chinese and American-Jewish cultures. Tham exposes the complexity of her life that is filled with both Asian-Chinese and American-Jewish spirits through her poetry, as an instrument to display her translation of various cultures to illustrate the complexities of her AsianAmerican identity. Although Tham is conscious of her role as a cultural mediator in communicating Asian-Chinese immigrants' cultural differences to her American audience, she negotiates the imbalanced power relations in most of the cultural issues and problematizes the "in-betweenness" of cultural identities, which culminates in the creation of a "Third Space" that fuses the East and the West as part of her cultural being. She is not politically neutral when negotiating the cultural differences between the Oriental and Occidental cultures because she degrades the Oriental cultures but dignifies the Western cultures, which are manifested in the selected poems in this study. She seems to show the superiority of Occidental culture, and especially glorifies the American culture, which is her adopted culture, rather than honour her Oriental culture roots. However, none of these cultures can ever dominate another culture, as they are neither superior nor inferior, but diverse in their unique way. As Ning (2003:34) states:

...observing the broad periphery outside of the centre: any culture exists in relation to another culture, any culture has its own strong points and weak points and no culture can avoid undergoing such periods as those of germination, development and prime of its life and decline. So no culture can forever dominate over world culture. Similarly, there is no such thing as a unidirectional influence of one culture on, or penetration into, another culture.

Apparently, different cultures possess different norms that are more or less alienated and "mysterious" to the others. However, it can be argued that the hyphenated identities negotiated in Tham's selected poems presuppose the Asian-American fixed identities of two polarizations that affords her direct access to the multicultural society and globalized world. In her works, she allows readers from various backgrounds to enter her space to learn more about her cultures and walk into her heterogeneous cultural upbringing. The focus on hyphenated identities through the lens of cultural translation in this paper contributes to creating cultural consciousness and mutual understanding of cultural variations between East-West cultures in Asian and American communities. 
INTERNATIONAL JOURNAL OF ACADEMIC RESEARCH IN BUSINESS AND SOCIAL SCIENCES

Vol. 8, No. 8, August 2018, E-ISSN: 2222-6990 C 2018 HRMARS

\section{Corresponding Author}

Khoo Siow See

School of Language Studies and Literature,

Faculty of Social Sciences and Humanities,

Universiti Kebangsaan Malaysia, Malaysia.

Email: khoosiowsee@gmail.com

\section{References}

Bassnett, S. \& A. Lefevere. (1998). Constructing Cultures: Essays On Literary Translation. Clevedon: Multilingual Matters.

Bery, A. (2007). Cultural Translation and Postcolonial Poetry. New York: Palgrave MacMillan.

Bhabha, H.K. (2006). Cultural Diversity and Cultural Differences. In Ashcroft, B. G. Griffiths and Tiffin, H.(Eds.). The Post-Colonial Studies Readers (pp.155-157). New York: Routledge.

Chan, K.S. (2012). A Localized Culture of Welfare: Entitlements, Stratification, and Identity in a Chinese Lineage Village. Lanham: Lexington Books.

Chua, A. (2011). Battle Hymm of the Tiger Mother. London: Bloomsbury.

Fadillah, M., Ruzy, S. H., Ganakumaran, S., and Raihanah M.M. (2004). Voices of Many Worlds, Malaysian Literature in English. Kuala Lumpur: Times Edition.

Hall, S. (2003). Cultural Identity and Diaspora. In Jana Evans Braziel and Anita Mannur (Eds.). Theorizing Diaspora (pp. 234-236). United Kingdom: Blackwell Publishing.

Katan, D. (2004). Translating Cultures: An Introduction for Translators, Interpreters and Mediators (2nd edition). London: Routledge.

Lambert, J. (2008). Medieval Translation and Translation Studies: Some Preliminary Considerations. In M. Goyens, P. d. Leemans and A. Smets (Eds.). Science Translated: Latin and Vernacular Translations of Scientific Treatises in Medieval Europe (pp.1-10). Belgium: Lueven University Press.

Lian, Y.S. (2013). New Chinese Immigrants in Japan: Cultural Translation and Linguistic Hybridity in Yang Yi's and Mao Danqing's Japanese Language Writing. Japan Language and Literature.Vol.47(2),193-234. Retrieved from http://www.jstor.org/stable/24394346.pdf (last accessed 5 July 2016).

Maitland, S. (2017). What is Cultural Translation? London: Bloomsbury.

Munday, J. (2016). Introducing Translation Studies: Theories and Applications Fourth Edition. London and New York: Routledge, Taylor and Francis Group. 
INTERNATIONAL JOURNAL OF ACADEMIC RESEARCH IN BUSINESS AND SOCIAL SCIENCES

Vol. 8, No. 8, August 2018, E-ISSN: 2222-6990 C 2018 HRMARS

Nor Faridah, A. M., \& M.A. Quayum. (2003). Colonial to Global: Malaysian Women's Writing in English 1940s-1990s. Kuala Lumpur: International Islamic University Malaysia.

Ratnasiri S., \& Bandara J. (2017). Changing patterns of meat consumption and greenhouse gas emissions in Australia: Will kangaroo meat make a difference? PLOS ONE 12(2): e0170130. https://doi.org/10.1371/journal.pone.0170130

Siti Aishah, K.A. (2005). A Critical Analysis of Hilary Tham's Memoir Lane With No Name Based on Her Poetic Works: A Gynocritic Reading. Dissertation M.A. National University of Malaysia.

Tham, H. (1987). Paper Boats. Washington, D.C: Three Continents Press.

Tham, H. (1989). Bad Names for Women. Washington, D.C: Word Works Capital Collection.

Tham, H. (1992). Tigerbone Wine. Washington, D.C: Three Continents Press.

Tham, H. (1994). Men and Other Strange Myths: Poems and Art. Colorado: Three Continents Press.

Tham, H. (1997). Lane With No Name: Memoirs and Poems of a Malaysian-Chinese Girlhood. Boulder and London: Lynne Rienner Publishers.

Tham, H. (2000). Counting. Washington, D.C: Capital Collection. The Word Works.

Tham, H. (2001). Reality Check and Other Travel Poems and Art. Florida: Kings Estate Press.

Tham, H. (2003). The Tao of Mrs. Wei. Washington, D.C: The Bunny and the Crocodile Press.

Wang, N. (2003). Globalization, cultural studies and translation studies. In Roland Robertson and Kathleen E.White. (Eds.). Globalization: Specialized applications and resistance to globalization, (pp. 29-38). London and New York: Routledge, Taylor and Francis.

Wang, N. (2008). On Cultural Translation: A Postcolonial Perspective. In Wang Ning and Sun Yifeng (Eds.) Translation, Globalisation and Localisation A Chinese Perspective, (pp.75-87). Clevedon: Multilingual Matters Ltd.

Wolf, M. (2000). The Third Space in Postcolonial Representation. In S. Simon and P. St.Pierre (Eds.) Changing the Terms: Translating in the Postcolonial Era (pp.127-146). Canada: University of Ottawa Press.

Xu, W. Y. (2008). Eating Identities: Reading Food in Asian American Literature. United States of America: University of Hawai'i Press. 